\title{
Modus Operandi Korupsi \\ dan Kaitannya dengan Aparatur Negara dalam Hadis-Hadis Nabi dan Perundang-Undangan di Indonesia
}

\section{(The Modus Operandi of Corruption and its Relation to the State Apparatus in the Prophet's Hadiths and Legislation in Indonesia)}

\author{
H. Rajab \\ Institut Agama Islam Negeri (IAIN) Ambon, Indonesia \\ rajabzeth@gmail.com
}

DOI: $10.29240 /$ alquds.v5i1.1936

Submitted: 2020-09-10 | Revised: 2021-03-09 | Accepted: 2021-03-28

\begin{abstract}
This paper aims to explain the modes of corruption and their relation to the state apparatus in the Prophet's traditions and legislation in Indonesia. So far, when many people talk about corruption, their memory is only of the laws that govern it, as if only the laws and regulations regulate corruption. In fact, long before the legislation was made, the Prophet, through his hadiths, have provided clues about corruption. This research is qualitative descriptive using a literature study that relies on library sources in the form of classic books, books, scientific journals, and other literature sources that are considered relevant. This study finds similarities between the Prophet's hadiths and Indonesian legislation in linking corruption (al-gulūl) to the state apparatus ('āmil) and that the modes of corruption are budget fraud, abuse of authority, embezzlement, and gratification and bribe. The mode then increases and develops with the times. Hopefully, through this writing, there will be awareness again that involvement in corruption is not only a violation of laws but also a violation of religious teachings and its legal consequences not only in the world but also in the hereafter
\end{abstract}

Keywords: Corruption, al-Gulūl, state apparatus, mode

Abstrak. Tulisan ini bertujuan menjelaskan modus-modus korupsi dan kaitannya dengan aparatur negara dalam hadis-hadis Nabi saw. dan perundang-undangan di Indonesia. Selama ini, banyak orang ketika berbicara tentang korupsi, ingatannya hanya kepada peraturan perundangan yang mengaturnya, seolah-olah hanya peraturan perundanganlah yang mengatur tentang korupsi. Padahal, jauh sebelum perundangan itu dibuat, Nabi saw. melalui hadis-hadisnya telah memberikan petunjuk-petunjuknya tentang korupsi. Penelitian bersifat kualitatif deskriptif dengan menggunakan studi kepustakaan yang mengandalkan sumber-sumber pustaka baik berupa kitab-kitab klasik, buku, jurnal ilmiah dan sumber pustaka lainnya yang dianggap relevan. Penelitian ini menemukan bahwa terdapat kesamaan antara hadis-hadis Nabi dengan perundang-undangan di Indonesia dalam mengaitkan korupsi (al-gulūl) dengan aparatur negara ('āmil) dan bahwa modus- 
modus korupsi adalah penyelewengan anggaran, penyalahgunaan kewenangan, penggelapan, serta gratifikasi dan suap. Modus itu kemudian bertambah dan berkembang seiring perkembangan zaman. Semoga melalui tulisan ini muncul kesadaran kembali bahwa keterlibatan dalam korupsi bukan hanya pelanggaran terhadap perundangundangan saja, tetapi juga tehadap ajaran agama dan kosekuensi hukumnya tidak hanya di dunia, tetapi juga di akhirat

Keyword: Korupsi, al-gulūl, aparatur negara, modus

\section{Pendahuluan}

Korupsi sampai saat ini masih menjadi salah satu isu besar Indonesia. Korupsi agaknya telah menjadi persoalan yang amat kronis. Laksana virus, korupsi telah menyebar luas ke seluruh negeri dengan jumlah yang dari tahun ke tahun cenderung semakin meningkat serta modus operandi yang makin beragam. Hasil riset yang dilakukan oleh berbagai lembaga, juga menunjukkan bahwa tingkat korupsi di negeri yang penduduknya mayoritas muslim ini termasuk tinggi di dunia. Bahkan koran Singapura, The Strait Time, sekali waktu pernah menjuluki Indonesia sebagai the envelope country, karena segala hal bisa dibeli, entah itu lisensi, tender, wartawan, hakim, jaksa, polisi, petugas pajak, atau yang lain. Pendek kata, segala urusan semua bisa lancar bila ada "amplop".

Dengan melakukan korupsi seseorang bisa mengumpulkan uang dalam jumlah yang cukup besar dalam jangka waktu yang relatif singkat. Pelakunya bukan saja pejabat tinggi tetapi juga pejabat level bawah bahkan menggurita sampai pejabat rakyat. Korupsi sangat merakyat dalam masyarakat, hal ini tergambar dari membuminya istilah uang minum, pelicin, biaya administrasi dan banyak lagi istilah lainnya yang sebenarnya tergolong dalam pungutan liar. ${ }^{2}$

Berbagai upaya telah dilakukan dalam rangka mengatasi penyakit korupsi ini, baik yang berhubungan dengan peraturan dan undang-undang maupun yang berkaitan dengan lembaga. Dari aspek peraturan dan undang-undang, sejak zaman Orde Baru, sampai sekarang, telah banyak dibuat, yang mengalami puncaknya dengan lahirnya Undang-undang Nomor No 39 Tahun 1999 tentang Tindak Pidana Korupsi, dan telah mengalami beberapa kali revisi. Dari segi lembaga, telah lahir pula Komisi Pembarantasan Korupsi melalui Undang-undang Nomor 30 Tahun 2002 tentang Komisi Pemberantasan Korupsi (KPK), yang dianggap sebagai lembaga super body dengan kewenangan yang lebih dibanding lembaga penegak hukum lainnya, seperti kepolisian, kejaksaan.

\footnotetext{
${ }^{1}$ Zainuddin Syarif, "Upaya Islam Dalam Membendung Budaya Korupsi,” KARSA: Journal of Social and Islamic Culture 17, no. 1 (2010): 51-58, doi:https://doi.org/10.19105/karsa.v17i1.95.

2 Sumarwoto, "Status Hukum Bagi Koruptor Menurut Hukum Islam," in Seminar Korupsi (Surakarta: Universitas Surakarta, 2014).
} 
Namun sebagai umat Islam, kepatuhan untuk tidak melakukan korupsi tidak seharusnya hanya mengacu pada peraturan perundang-undangan saja, tetapi jauh lebih penting adalah kepatuhan terhadap ajaran-ajaran agama. Jauh sebelum peraturan perundang-undangan dibuat, Nabi Muhammad saw. telah memberikan petunjuk-petunjuk dan rambu-rambu kepada umatnya untuk menghindari perbuatan koruptif. Dalam hadis-hadis itu, terlihat dengan jelas bahwa korupsi selalu dikaitkan dengan mereka yang melaksanakan tugas-tugas tertentu dengan penghasilan dari negara. Mereka adalah para 'ämil ('ummä) yang bisa dipadankan dengan aparatur negara saat ini.

Pertanyaan penelitian ini adalah bagaimanakah modus operandi korupsi dan kaitannya dengan aparatur negara dalam hadis-hadis Nabi saw. dan perundang-undangan di Indonesia. Penelitian bersifat deskriptif kualitatif dengan mengandalkan sumber data kepustakaan, berupa hadis-hadis Nabi saw. dari sumbernya yang asli dan komentar-komentar ulama tentang hadis itu dan tulisantulisan lain yang dianggap relevan, juga berbagai perundang-undangan yang ada di Indonesia yang mengatur tentang korupsi.

Penelitian tentang modus operandi korupsi telah dilakukan oleh beberapa orang peneliti, misalnya Muhammad Reza Kurniawan dan Pujiono melakukan penelitian tentang "Modus Operandi Korupsi Pengadaan Barang dan Jasa Pemerintah oleh PNS" dalam Jurnal Law Reform tahun 2018. ${ }^{3}$ Penelitian yang memfokuskan melakukan penelitian pada kasus tindak pidana korupsi yang terjadi di Kota Salatiga pada tahun 2009 s/d 2014 menemukan bahwa modus operandi korupsi yang dilakukan oleh PNS paling menonjol adalah penunjukan langsung, terjadinya mark up anggaran karena tidak melakukan survey dalam menentukan harga barang dan pembayaran lunas terhadap penyedia jasa sebelum pekerjaannya selesai. ${ }^{4}$ Penelitian lainnya dilakukan oleh Yusrianto Kadir, tentang "Pencegahan Korupsi dalam Pengelolaan Dana Desa" dalam Jurnal IUS. ${ }^{5}$ Merujuk Peneliti ICW, Egi Primayoga, Yusrianto menyimpulkan adanya sejumlah modus operandi korupsi dana desa, yaitu kepala desa yang mempertanggung jawabkan pembiayaan bangunan dana desa padahal sumber pendanaannya berasal dari sumber lain, meminjam sementara dana desa dengan memindahkan dana desa ke rekening pribadi yang kemudian tidak dikembalikan, pemotongan dana desa oleh oknum, membuat perjalanan dinas fiktif, mark up pembayaran honorarium perangkat desa, pembayaran

${ }^{3}$ Muhammad Rezza Kurniawan and Pujiyono Pujiyono, "Modus Operandi Korupsi Pengadaan Barang Dan Jasa Pemerintah Oleh Pns," Law Reform 14, no. 1 (2018): 115, doi:10.14710/lr.v14i1.20241.

${ }^{4}$ Ibid., 123.

${ }^{5}$ Yusrianto Kadir and Roy Marthen Moonti, "Pencengahan Korupsi Dalam Pengelolaan Dana Desa," Jurnal IUS (Kajian Hukum Dan Keadilan) 6, no. 3 (2018): 431-42, doi:http://dx.doi.org/10.29303/ius.v6i3.583. 
ATK yang tidak sesuai dengan real cost, memungut pajak yang hasilnya tidak dimasukan ke kantor pajak, melakukan pembelian inventaris kantor dengan dana desa namun diperuntukkan untuk kepentingan pribadi. ${ }^{6}$ Penelitian lainnya ditulis oleh Rasina Padeni Nasution dengan judul "Proyek Fiktif sebagai Modus Operandi Korupsi” dalam Jurnal Taqnin tahun $2020 .{ }^{7}$ Rasina melihat bahwa proyek fiktif menjadi salah satu modus operasi korupsi yang paling marak belakangan ini. Rasina mengacu pada kasus penetapan dua pejabat PT Waskita Karya (Persero) Tbk. sebagai tersangka korupsi 14 proyek infrastruktur fiktif, Senin (17/12/2018). Kedua pegawai Badan Usaha Milik Negara (BUMN) ini diduga menunjuk beberapa perusahaan subkontraktor untuk mengerjakan sejumlah proyek yang sebenarnya sudah dikerjakan oleh perusahaan lain. ${ }^{8}$

Penelitian-penelitian tersebut menunjukkan bahwa memang ada hubungan antara korupsi dengan aparatur negara, baik PNS maupun pejabat negara lainnya. Namun penelitian-penelitian tersebut hanya mengaitkan korupsi dengan ketentuan-ketentuan dalam peundang-undangan yang berlaku. Berbeda dengan penelitian ini memfokuskan pada penjelasan bahwa modus-modus operandi korupsi yang dilakukan oleh aparatur negara dapat ditemukan rujukannya pada hadis-hadis Nabi saw. sebagai sumber kedua ajaran Islam setelah al-Quran, sehingga dengan demikian dapat dikatakan bahwa korupsi bukan hanya pelanggaran atas ketentuan perundang-undangan yang berlaku sebagai warga negara, tetapi juga merupakan pelanggaran terhadap ketentuan-ketentuan agama. Melalui penelitian ini diharapkan akan memunculkan kesadaran kepada semua orang bahwa keterlibatan dalam perbuatan korupsi, selain dapat berdampak duniawi berupa hukuman penjara dan hukuman lainnya, karena melanggar peraturan perundangan yang berlaku, juga akan berakibat siksa di akhirat dalam bentuk hukuman neraka, karena telah melanggar aturan-aturan agama.

\section{Korupsi dan Aparatur vs al-gulūl dan 'āmil}

Secara etimologi, kata korupsi menurut Fockema Andrea, sebagaimana dikutip dari Abvianto Syaifulloh, berasal dari bahasa Latin corruptio atau corruptus. Selanjutnya disebutkan bahwa corruptio itu berasal pula dari kata corrumpere, suatu kata Latin yang lebih tua. Dari bahasa Latin itulah diserap ke banyak bahasa Eropa, seperti Inggris, yaitu corruption, corrupt; Prancis, yaitu corruption; dan Belanda, yaitu corruptie (korruptie). ${ }^{9}$ Dalam Kamus Besar Bahasa Indonesia disebutkan bahwa korup berarti 1) buruk; rusak; busuk; 2) suka menerima uang

\footnotetext{
${ }^{6}$ Ibid., 441.

${ }^{7}$ Rasina Padeni Nasution, "Proyek Fiktif Sebagai Modus Korupsi Di Indonesia," TAQNIN: Jurnal Syariah Dan Hukum 2, no. 02 (2020): 53-65, doi:10.30821/taqnin.v2i02.8438.

${ }^{8}$ Ibid., 61

${ }^{9}$ Abvianto Syaifulloh, "Peran Kejaksaan Dalam Pengembalian Kerugian Keuangan Negara Pada Perkara Tindak Pidana Korupsi," Indonesian Journal of Criminal Law 1, no. 1 (2019): 47-64, doi:10.31960/ijocl.v1i1.147.
} 
sogok; dapat disogok (memakai kekuasaannya untuk kepentingan pribadi), sedangkan korupsi adalah penyelewengan atau penyalahgunaan uang negara (perusahaan, organisasi, yayasan, dan sebagainya) untuk keuntungan pribadi atau orang lain. ${ }^{10}$

Ada banyak definisi dikemukakan oleh para pakar tentang korupsi dan di sana sini terdapat banyak perbedaan, dan sampai saat ini belum ada satu definisi yang menjadi satu-satunya acuan di seluruh dunia tentang apa yang dimaksud dengan korupsi. Tulisan ini tak akan terjebak dalam diskusi tak berkesudahan tentang definisi tersebut. Korupsi yang dimaksudkan dalam tulisan ini adalah sebagaimana ditegaskan dalam Undang-undang Nomor 28 Tahun 1999 tentang Penyelenggaraan Negara yang Bersih dan Bebas dari Korupsi, Kolusi dan Nepotisme. Pada Pasal 1 butir 3, dimuat pengertian korupsi, yaitu "korupsi adalah tindak pidana sebagaimana dimaksud dalam ketentuan peraturan perundangundangan yang mengatur tentang tindak pidana korupsi”. Peraturan perundangundangan dimaksud adalah Undang-undang No. 31 Tahun 1999 tentang Pemberantasan Tindak Pidana Korupsi. Korupsi dalam Undang-undang yaitu setiap orang yang dikategorikan melawan hukum, melakukan perbuatan memperkaya diri sendiri, menguntungkan diri sendiri atau orang lain atau suatu korporasi, menyalahgunakan kewenangan maupun kesempatan atau sarana yang ada padanya karena jabatan atau kedudukan yang dapat merugikan keuangan negara atau perekonomian negara. ${ }^{11}$

Dari definisi tersebut tampak bahwa korupsi dilakukan oleh orang karena jabatan dan kedudukannya mampu melakukan penyalahgunaan kewenangan maupun kesempatan atau sarana yang ada padanya. Atas dasar ini, Firman Wijaya mengatakan subjek delik dalam Undang-undang pemberantasan tindak pidana korupsi haruslah pegawai negeri sipil atau penyelenggara negara karena perbuatan penyalahgunaan wewenang hanya dapat dilakukan oleh pegawai negeri atau pejabat yang diberikan wewenang menjalankan pelayanan publik. ${ }^{12}$

Pada mulanya pemberantasan korupsi di seluruh negara memiliki sasaran yang sama yaitu hanya ditujukan terhadap pejabat pemerintah. Sasaran tersebut sangat masuk akal karena korupsi hanya dapat dilakukan oleh mereka yang memiliki wewenang atau sedang menjalankan jabatan pemerintah. Namun sejak

\footnotetext{
${ }^{10}$ Departemen Pendidikan Nasional, Kamus Besar Babasa Indonesia (Jakarta: PT. Gramedia Pustaka Utama, 2008)., 736.

${ }^{11}$ Republik Indonesia, “Undang-Undang Republik Indonesia Nomor 31 Tahun 1999 Tentang Pemberantasan Tindak Pidana Korupsi," 1999, 1-30.

12 Ari Wibowo, "Penentuan Kriteria Unsur Penyalahgunaan Wewenang Dalam Perkara Tindak Pidana Korupsi (Studi Putusan Pengadilan)," Jurnal Yuridis 7, no. 1 (2020): 120-48, doi:http://dx.doi.org/10.35586/jyur.v7i1.
} 
berlakunya UU No. 31 tahun 1999, subjek hukum tindak pidana korupsi bukan hanya termasuk pegawai negeri, melainkan juga termasuk korporasi dan orang perorangan. ${ }^{13}$ Arif Suhartono menjelaskan bahwa Undang-undang No. 31 Tahun 1999 menggunakan istilah setiap orang, yang kemudian dalam pasal 1 ke 3 diatur bahwa yang dimaksud dengan setiap orang adalah orang perseorangan termasuk korporasi. Kemudian terdapat secara khusus di dalam pasal-pasal tertentu bahwa subjeknya adalah pegawai negeri, sehingga subjek hukum dalam tindak pidana korupsi meliputi pegawai negeri, penyelenggara negara; dan perseorangan termasuk korporasi. ${ }^{14}$

Dengan demikian, subjek hukum perbuatan korupsi adalah pegawai negeri, dan penyelenggara negara lainnya serta korporasi dan perseorangan. Mereka inilah yang dianggap memiliki akses ke keuangan negara, sehingga peluang untuk penyelewengan keuangan negara itu hanya mereka yang dapat melakukannya. Baik pegawai negeri, maupun penyelenggara lainnya adalah aparatur negara. Istilah "aparatur" berasal dari kata aparat yakni alat, badan, instansi, pegawai negeri. Sedangkan aparatur dapat diartikan sebagai alat negara, aparat pemerintah. Jadi aparatur negara, adalah alat kelengkapan negara yang terutama meliputi bidang kelembagaan, ketatalaksanaan dan kepegawaian, yang mempunyai tanggung jawab melaksanakan roda pemerintahan sehari-hari. Dengan demikian pengertian aparatur tidak hanya dikaitkan dengan orangnya, tetapi juga organisasi, fasilitas, ketentuan, pengaturan dan sebagainya. ${ }^{15}$

Ada 2 jenis aparatur yang dikenal dalam sistem pemerintahan di Indonesia, yaitu:

1. Aparatur negara, yaitu keseluruhan pejabat dan lembaga negara serta pemerintahan negara yang meliputi aparatur kenegaraan dan pemerintahan, sebagai abdi negara dan abdi masyarakat bertugas dan bertanggung jawab atas penyelenggaraan negara dan pembangunan serta senantiasa mengabdi dan setia kepada kepentingan, nilai-nilai dan cita-cita perjuangan bangsa dan negara berdasarkan Pancasila dan UUD 1945; dan

2. Aparatur pemerintah adalah keseluruhan lembaga atau badan yang ada di bawah presiden seperti departemen, lembaga, pemerintahan dan

${ }^{13}$ Gatot Triyanto, "Ratio Legis Perbedaan Rumusan Delik Pasal 2 Dan Pasal 3 UndangUndang Nomor 31 Tahun 1999 Jo. Undang-Undang No. 20 Tahun 2001 Tentang Pemberantasan Tindak Pidana Korupsi," RECHTENS Volume VI (2017): 46-65.

14 Arif Suhartono, "Subyek Hukum Tindak Pidana Korupsi," 2012, http://jpuarifsuhartono.blogspot.com/2012/06/subyek-hukum-tindak-pidana-

korupsi.html\#: :text=Subyek hukum adalah orang yang,adalah orang perseorangan termasuk korporasi.

15 Theresia C. Tambayong, "Profesionalisme Birokrasi Aparat Pemerintah Dalam Pelaksanaan Pelayanan Publik Di Kecamatan Tomohon Selatan Kota Tomohon," Politico V, no. 1 (2016). 
departemen serta sekretariat departemen dan lembaga-lernbaga tinggi negara. ${ }^{16}$

Dengan demikian, aparatur negara yang dimaksudkan dalam tulisan ini adalah keseluruhan pejabat dan lembaga negara serta pemerintahan negara yang meliputi aparatur kenegaraan dan pemerintahan yang bertugas dan bertanggung jawab atas penyelenggaraan negara dan pembangunan. Termasuk di dalamnya pegawai negeri dan penyelenggara negara lainnya, yang selalu dikaitkan sebagai subjek dalam perbuatan korupsi dalam berbagai Undang-undang.

Dalam Islam, istilah korupsi dapat dipadankan dengan istilah al-gulül. Secara etimologis, kata al-gulül berasal dari kata kerja galla - yagullu, yang dapat diartikan dengan al-khiyanah (penyelewengan), dapat pula berarti al-ikhfa (penggelapan). Dimaknai al-khiyänah karena al-gulül digunakan untuk penyelewengkan sesuatu dari gudang penyimpanan ganimah (rampasan perang) atau mencuri harta-harta itu sebelum dibagi. Ada yang berpendapat bahwa kata al-gulül ini hanya untuk penyelewengan yang terkait dengan ganimah, sedangkan untuk kecurangan lain digunakan kata al-igläl, ${ }^{17}$ Al-gulül secara bahasa juga bisa berarti al-ikhfä' (penggelapan). Ibnu Hajar mengatakan al-gulül disebut penggelapan karena pelakunya menyembunyikan (harta yang diambilnya) dalam harta miliknya dan menyamarkan pada hartanya itu. Pendapat ini dikuatkan oleh al-Qurthūbi yang mengatakan bahwa al-gulül adalah seseorang mengambil sesuatu dari tempat ganimah dan menyembunyikannya dari pemiliknya. ${ }^{18}$ Jadi, ada dua makna yang terkandung dalam kata al-gulül menurut bahasa, yang keduanya saling berkaitan satu sama lain, yaitu penyelewengan dan penggelapan. Penyelewengan harta dilakukan dengan cara disamarkan pada harta lain, atau sebaliknya, harta yang disamarkan itu adalah hasil dari penyelewengan.

Secara terminologis, menurut al-Kafawi, al-gubül adalah penyelewengan pada harta bait al-māl, harta zakat dan harta rampasan perang. ${ }^{19}$ al-Nawāwī menyebut pendapat Abū Ubaid bahwa al-gulül hanya digunakan untuk menyebut penyelewengan pada harta ganimah saja, tapi ada ulama lain yang mengatakan algulül dapat digunakan menyebut penyelewengan pada harta ganimah dan selainnya. ${ }^{20}$ Menurut Ibnu Hajar, al-gulül pada rampasan perang adalah tindakan

16 Ibid., 6-7.

${ }^{17}$ Jamāluddīn Muḥammad bin Mukarram al-Ifrī $1 \overline{1}$ al-Missī Ibnu Manzur, Lisān Al-Arab, XI (Beirut: Dār al-Sādir, 1994)., 500.

${ }^{18}$ Șāliḥ bin Abdillāh bin Ḥamīd, Naḍrat Al-Na‘ìm Fi Akblāq al-Rasūl al-Karìm, XI (Jeddah: Dār al-Wasīlah, n.d.)., 5130

${ }^{19}$ Ibid.

${ }^{20}$ Abū Zakariyā al-Nawawī, Al-Minhäj Sharḥ Șaḥịh Muslim Bin al-Haijäj, II (Bairut: Dār Iḥyā al-Turāth al-Arabī, n.d.)., 127. 
tertentu yang dilakukan seorang (tentara) yang terlibat perang, baik ia seorang raja atau pun bukan, mengambil sejumlah barang dari harta rampasan perang tanpa membawanya ke hadapan komandan pasukan untuk dibagi, sekalipun yang diambilnya itu hanya sedikit. ${ }^{21}$ Sedangkan Menurut Ibn al-'Athīr, kata al-gulül digunakan berkali-kali dalam hadis, artinya adalah kecurangan berkaitan dengan harta rampasan perang dan mencuri dari harta rampasan perang sebelum pembagian, namun setiap penyelewengan dalam hal apapun dan dilakukan dengan sembunyi-sembunyi dapat dinamakan dengan al-gulül.22

Jadi intinya, al-gulül adalah penyelewengan atas kekayaan negara yang dilakukan dengan cara menggelapkan kekayaan negara itu dan menyamarkannya dalam harta miliknya sendiri. Dalam kenyataanya, dalam hadis-hadis Nabi saw. seperti yang akan terlihat nanti, kata al-gulül tidak hanya dipakai untuk menyebut penyelewengan harta ganimah dan harta yang timbul dari hasil perang lainnya, tetapi juga dipakai untuk menyebut penyelewengan atas harta milik bersama lainnya yang dikelola oleh negara Islam, seperti harta hasil pengumpulan zakat dan harta hasil filantropi Islam lainnya.

Adapun aparatur negara dapat dipadankan dengan istilah 'ámil atau 'ámilīn dan 'ummäl dalam bentuk jamak. Kata 'ámil dalam banyak literatur lebih banyak dipahami sebagai pegawai pungumpul zakat, 'àmil al-Șadaqah atau 'ämil al-z̧akāh, tampaknya karena kata 'ämil ini digunakan dalam QS. Al-Taubah 9/60, dalam pengertian ini yaitu untuk menyebut salah satu golongan yang berhak mendapatkan pembagian zakat, al-'́amilìn alaihà (para pegawai yang bertugas mengumpulkan dan mendistribusikan zakat). Dalam pengertian tersebut, bukan berarti kata 'amil hanya digunakan untuk pegawai zakat saja, tetapi dalam sejarah pemerintahan Islam, kata 'amil juga digunakan sebagai sebutan bagi seorang kepala daerah semacam gubernur kepala daerah tingkat I pada zaman sekarang. Istilah ini telah digunakan sejak zaman al-Khulafä al-Räsyidūn, masa Dinasti Umayyah dan di awal masa Dinasti Abbasiyah. 'Ummal berarti gubernur-gubernur atau penguasa daerah. Para petugas pengumpul pajak dan jizyah di masa Khalifah Umar bin Khattab juga disebut 'ummal. Pada perkembangannya, kata 'ámil juga digunakan untuk menunjukkan jenjang atau tingkatan jabatan pemerintahan, dari yang terendah hingga yang tertinggi. Ketika bidang keuangan dipisahkan dari administrasi lainnya, kata 'ämil mulai digunakan untuk menyebut jabatan seorang direktur keuangan yang berkedudukan di ibukota provinsi, misalnya Mesir dan Khurasan (Iran) - ketika dua wilayah itu menjadi bagian dari provinsi Dinasti Abbasiyah yang berpusat di Bagdad. Pada era kekuasaan Dinasti Umayyah dan Abbasiyah, kata 'ummāl juga digunakan untuk para petugas pemungut pajak. Pada

\footnotetext{
${ }^{21} \mathrm{Hamīd}, \mathrm{Na}$ drat Al-Naìm Fi Akblāq al-Rasūl al-Karim.

${ }^{22}$ Majduddīn ibn Al-Athīr, Al-Nibāyat Fì Garì al-Hadìth, XIII (Beirut: al-Maktabat al'Ilmiyyah, 1978)., 380
} 
zaman Abbasiyah ditunjuk oleh pemerintah pusat di Bagdad. Selain itu, kata ämil juga pernah digunakan untuk menyatakan orang-orang yang mengemban dan mempertanggungjawabkan suatu tugas tertentu, misalnya 'ámil ma'áwin yang berarti petugas kepolisian. 'Ámil ditunjuk langsung oleh khalifah atau wazir (perdana menteri), sedangkan 'ámil boleh menunjuk 'ummäl di daerah. ${ }^{23}$

Jadi, istilah 'amil cakupannya sangat luas, meliputi semua orang yang ditugaskan dan bekerja untuk negara. Istilah ini mirip dengan istilah aparatur negara dalam konteks kekinian yang tidak hanya mencakup pegawai negeri saja, tetapi juga pejabat dan penyelenggara negara lainnya. Di sini terlihat adanya kesamaan konsep tentang subjek korupsi antara hadis-hadis Nabi saw. dengan perundang-undangan di Indonesia. Sejak awal, Islam telah mengaitkan perbuatan korupsi al-gulül dengan 'ámil, pegawai yang diberi tugas tertentu oleh negara dan diberi penghasilan dari negara untuk tugasnya itu. Sedangkan perundangundangan di Indonesia, korupsi selalu dikaitkan dengan aparatur negara sebagai subjek.

\section{Modus Operandi Korupsi dan Kaitannya dengan Aparatur}

"Modus operandi" berasal dari bahasa Latin, artinya 'prosedur atau cara bergerak atau berbuat sesuatu'. Secara leksikal istilah modus operandi diartikan sebagai cara atau teknik yang berciri khusus dari seorang atau kelompok penjahat dalam melakukan perbuatan jahatnya yang melanggar hukum dan merugikan orang lain, baik sebelum, ketika, dan sesudah perbuatan kriminal tersebut dilakukan. $^{24}$ Jadi Modus operandi korupsi atau biasa disebut dengan modus korupsi saja adalah cara operasi orang perorang atau kelompok dalam menjalankan rencana kejahatan dalam bentuk korupsi.

Korupsi sebagai suatu pelanggaran hukum dilakukan dengan berbagai macam modus, antara lain:

1. Modus Penyalahgunaan Anggaran

Modus penyalahgunaan anggaran memiliki ciri umum yang terjadi pada semua perbuatan korupsi, yaitu penyelewengan atau penyalahgunaan anggaran berupa keuangan negara. Dalam hadis Nabi saw. modus ini disebut mengambil sesuatu di luar penghasilan resmi yang diberikan kepadanya. Sabda Nabi saw.:

23 Agus Sasongko, "Menjadi Amil, Apa Syaratnya?," Republika.Co.Id, 2019, https://republika.co.id/berita/dunia-islam/wakaf/pnxs74313/menjadi-amil-apa-syaratnya.

${ }^{24}$ Kurniawan and Pujiyono, "Modus Operandi Korupsi Pengadaan Barang Dan Jasa Pemerintah Oleh Pns.”, 119 


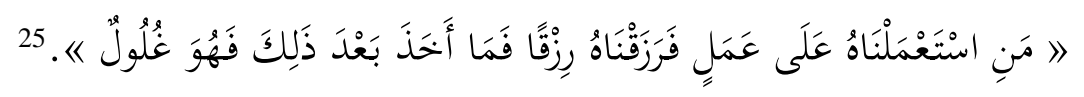

Siapa saja yang kami pekerjakan untuk suatu pekerjaan dan kami beri ia reqki (penghasilan), maka apa pun yang ia ambil di luar daripenghasilan yang ditentukan itu adalah gulül (korupsi) (HR. Abü Däwüd).

Dalam konteks Islam, setiap pegawai atau aparatur diberi gaji atas pekerjaan yang dilakukannya. Gaji ini tentu saja diambil dari kas negara, yang di masa Nabi saw. disebut bait al-mäl. Oleh karena sudah diberi gaji, maka pegawai tersebut tidak lagi boleh mendapatkan penghasilan lain atas pekerjaan yang dilakukannya di luar gajinya itu. Gaji dimaksud di sini adalah semua penghasilan resmi untuk menunjang tugas-tugasnya, dari gaji tetap, uang transport, tunjangantunjangan dan lain-lain. Jika ternyata ia mendapatkan penghasilan di luar gaji resmi itu, maka itulah yang disebut korupsi.

2. Modus Penyalahgunaan Kewenangan

Modus lain korupsi adalah penyalahgunaan kewenangan. Setiap aparatur, baik di masa Nabi saw. maupun di masa sekarang, diberi tugas dan kewenangan tertentu dengan gaji tertentu pula yang sudah jelas aturannya. Seorang pegawai tidak boleh memanfaatkan kedudukannya itu untuk menyalahgunakan kewenangan yang ada padanya. Dalam salah satu hadis Nabi saw. dikisahkan bahwa seorang budak bernama Mid'am ditugaskan oleh Nabi saw. untuk membawa sejumlah harta ganimah atau hasil rampasan perang Khaibar. Dalam sebuah perjalanan, tepatnya di Wâd al-Qurâ, tiba-tiba Mid'am terkena bidikan nyasar, salah tembak. Sebuah anak panah menusuk lehernya sampai dia meninggal dunia. Para sahabat Nabi kaget, mereka serentak mendoakan Mid'am semoga ia masuk surga. Di luar dugaan mereka, Rasulullah saw. tiba-tiba bersabda:

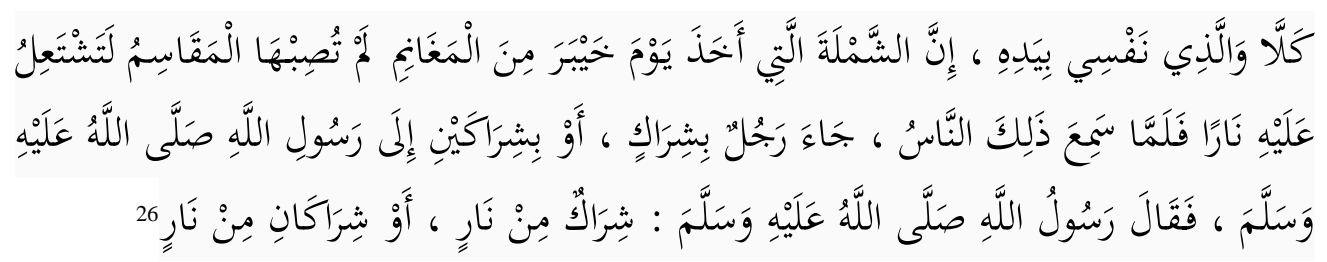

"Tidak demi Allah yang diriku berada di tanganNya, sesunggubnya mantel yang diambilnya pada waktu penaklukan Khaibar dari rampasan perang yang belum dibagikan akan menyulut api neraka yang akan membakarnya. Ketika orang-orang mendengar pernyataan Rasulullah itu ada seorang lelaki datang kepada Rasulullah saw membawa seutas tali sepatu atau dua utas tali sepatu. Ketika itu, Nabi saw. mengatakan: seutas tali sepatu sekali pun akan menjadi api neraka." (HR. Abu Dawnd).

${ }^{25} \mathrm{Abū}$ Dāwūd Al-Sijistānī, Sunan Abì Dāwñ̄d (Bairut: al-Maktabat al-Așriyyah, n.d.)., 94.

${ }^{26}$ Ibid., Juz IV, 345 
Mid'am yang ditugaskan untuk membawa dan menjaga ganimah, ternyata justru ia memanfaatkan kedudukannya itu untuk mengambil mantel dari ganimah sebelum dibagikan. Ini adalah petunjuk dari Nabi saw. untuk tidak menganggap enteng korupsi. Jangan karena nilainya yang kecil lantas dengan mudah melakukan korupsi. Dalam Islam, tidak ada perbedaan korupsi yang kecil dan yang besar. Semua hasil korupsi itu akan menjadi api neraka di akhirat nanti.

\section{Modus Penggelapan}

Penggelapan menurut Kitab Undang-undang Hukum Pidana (KUHP) adalah perbuatan mengambil barang milik orang lain (sebagian atau seluruhnya) di mana penguasaan atas barang itu sudah ada pada pelaku, tapi penguasaan itu terjadi secara sah. Misalnya, penguasaan suatu barang oleh pelaku terjadi karena pemiliknya menitipkan barang tersebut. Atau penguasaan barang oleh pelaku terjadi karena tugas atau jabatannya, misalnya petugas penitipan barang. Tujuan dari penggelapan adalah memiliki barang atau uang yang ada dalam penguasannya yang mana barang/uang tersebut pada dasarnya adalah milik orang lain. ${ }^{27}$ Penggelapan dianggap korupsi, jika barang atau uang yang digelapkan adalah barang atau uang milik negara.

Nabi saw. pernah bersabda:

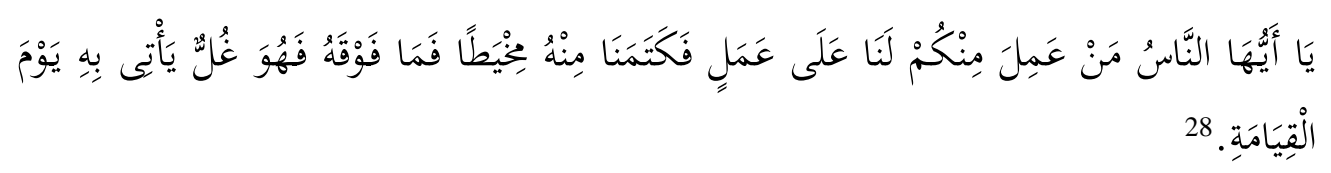

wahai sekalian manusia, siapa saja di antara kalian yang bekerja untuk kami pada suatu tugas tertentu, lalu ia menyembunyikan sesuatu dari kami, sekecil jarum pun atau lebih besar, maka perbuatan itu adalah gulül (korupsi) yang akan dipertanggung jawabkannya di hari kiamat.

Di hadis ini terdapat pernyataan "siapa saja yang bekerja untuk kami”, maksud kata kami dalam kalimat tersebut adalah Rasulullah saw. sebagai kepala negara dan pemerintahan Islam pada saat itu. Jadi yang dimaksud adalah aparatur negara dan pemerintahan. Di sini Nabi saw. menekankan bahwa harta sekecil apapun yang diambil, disembunyikan, atau tidak dilaporkan dari harta milik negara, meskipun itu hanya sekecil jarum, maka itu adalah korupsi dan akan dipertanggung jawabkan di hadapan Tuhan di akhirat nanti. Inilah konsep korupsi dalam Islam. Pegawai negara telah digaji untuk pekerjaan yang dilakukannya. Karena itu, ia tidak lagi boleh mengambil penghasilan lain sekecil apapun. Jika ia

\footnotetext{
${ }^{27}$ Jastianra Mamalu, "Penggelapan Barang Sitaan Narkotika Dalam Perkara Tindak Pidana," Lex et Societatis II, no. 2 (2014): 15-22.

${ }_{28}$ Al-Sijistānī, Sunan Abì Dāwñ̀d., Juz III, 327
} 
ditugaskan untuk mengumpulkan uang atau barang untuk negara, maka semuanya harus dilaporkan ke negara, tidak boleh diambil atau tidak dilaporkan. Demikian juga, jika ia diberi tugas tertentu, lalu terdapat kelebihan dana yang diberikan kepadanya, maka kelebihan itu harus dikembalikan. Tidak boleh diselewengkan apalagi dikuasai sendiri.

Dikisahkan dalam satu hadis, bahwa seorang sahabat Nabi yang meninggal dunia pada waktu terjadi peristiwa penaklukan Khaibar. Hal ini dibicarakan oleh mereka hingga sampai didengar Rasulullah saw. Lantas Nabi saw. bersabda:

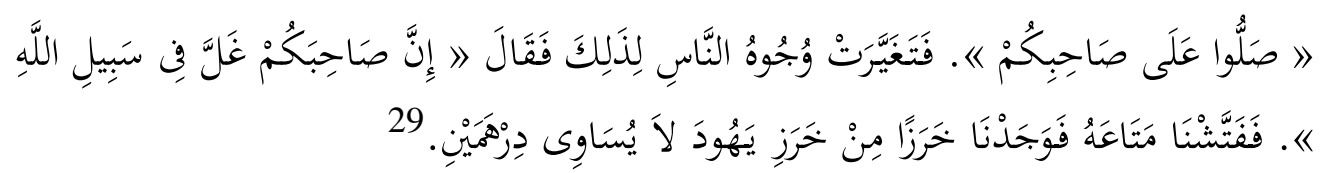

"Salatilah saudara kalian ini". Pada saat itu raut muka para sababat berubah (karena keheranan dengan perintah Nabi ini). Rasulullah saw. melanjutkan, "Sunggub saudara kalian ini menggelapkan harta rampasan perang di jalan Allab". Ketika itu, kami langsung memeriksa harta bawaannya dan ternyata kami menemukan kharaz. (perbiasan/manikmanik. atau permata orang Yabudi yang harganya tidak mencapai dua dirbam. (HR. Abu Dawnd).

Penggelapan sudah terjadi sejak zaman Nabi saw. dan dilakukan oleh aparatur negara. Dalam contoh hadis yang terakhir, pelakunya adalah prajurit yang terlibat dalam penaklukan Khaibar. Korupsi tidak hanya dilakukan oleh aparatur sipil negara, tetapi juga aparatur non sipil.

4. Modus Gratifikasi

Dalam penjelasan Pasal 12B (1) UU No. 20 Tahun 2001 disebutkan bahwa arti gratifikasi adalah pemberian dalam arti luas, yakni meliputi pemberian uang, barang, rabat (discount), komisi, pinjaman tanpa bunga, tiket perjalanan, fasilitas penginapan, perjalanan wisata, pengobatan cuma-cuma, dan fasilitas lainnya. Gratifikasi tersebut baik yang diterima di dalam negeri maupun di luar negeri dan yang dilakukan dengan menggunakan sarana elektronik atau tanpa sarana elektronik. Pemberian tersebut dinilai sebagai gratifikasi jika diberikan kepada pegawai negeri atau penyelenggara negara dan pemberian tersebut berhubungan dengan jabatan pegawai yang bersangkutan dan berlawanan dengan kewajiban atau tugasnya. ${ }^{30}$

Definisi di atas menunjukkan bahwa gratifikasi sebenarnya bermakna pemberian yang bersifat netral, belum tentu baik, dan belum tentu buruk. Gratifikasi juga belum tentu berarti suap, sebab suatu pemberian menjadi

\footnotetext{
${ }^{29}$ Ibid. 274

30 Topo Santoso, "Menguak Relevansi Ketentuan Gratifikasi Di Indonesia," Jurnal Dinamika Hukum 13, no. 3 (2013): 402-14.
} 
gratifikasi yang dianggap suap jika terkait dengan jabatan dan bertentangan dengan kewajiban atau tugas penerima. Hal ini perlu ditegaskan mengingat selama ini masih terdapat kerancuan berpikir seolah-olah delik gratifikasi merupakan bentuk lain dari suap atau menyamakan delik gratifikasi dengan suap. Pada Pasal 12 B dan 12 C Undang-undang Pemberantasan Tindak Pidana Korupsi tersebut diatur mengenai delik gratifikasi, mengatur ancaman pidana bagi setiap pegawai negeri/penyelenggara negara yang menerima segala bentuk pemberian yang tidak sah dalam pelaksanaan tugasnya, atau yang diistilahkan sebagai gratifikasi yang dianggap suap dan tidak melaporkannya pada KPK dalam jangka waktu paling lama 30 hari kerja. ${ }^{31}$

Senada dengan ketentuan dalam perundang-undangan, dalam Islam pemberian dalam arti umum (gratifikasi) juga bersifat netral. Bahkan bisa dikatakan dianjurkan oleh Nabi saw. dalam hadis-hadisnya. Misalnya, Nabi saw. pernah bersabda:

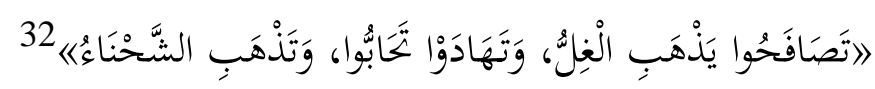

Saling berjabat tanganlah kalian, maka korupsi akan bilang dan saling memberi hadiablah, maka kamu akan saling menyayangi dan akan hilang rasa dendam. (HR. Malik)

Nabi saw. mengatakan bahwa saling memberi dapat menimbulkan rasa kasih sayang di antara sesama manusia dan menghilangkan rasa dendam. Tentu saja yang dimaksud oleh hadis ini adalah pemberian dalam arti umum, yang dilakukan secara ikhlas tanpa pamrih, dan tidak berkaitan dengan jabatan yang dipegang oleh salah satu yang terlibat dalam pemberian itu, sebab Nabi saw. di hadisnya yang lain justru melarang pemberian (hadiah) ini, jika diberikan kepada atau dilakukan oleh aparatur negara. Nabi saw. bersabda:

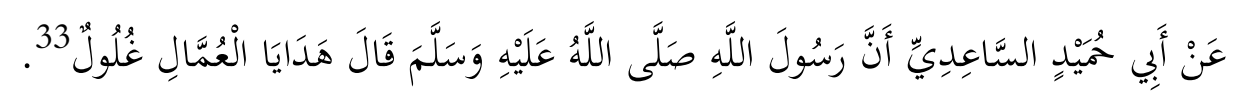

Dari Abu Humaid al-Saidi, Rasulullah saw. telah bersabda: "pemberian hadiah terhadap 'ummäl adalah gulül'. (HR. Ahmad)

Hadiah kepada para pegawai negara adalah korupsi menurut hadis ini. Alasannya, karena dengan adanya hadiah itu dikhawatirkan akan berpengaruh terhadap sikap pegawai kepada orang yang memberinya hadiah. Abu Dawud al-

${ }^{31}$ Mardiana Arsjad, "Gratifikasi Pelayanan Seksual Sebagai Tindak Pidana Korupsi," Jurnal Akta Yudisia 3, no. 1 (2018), doi:10.35334/ay.v3i1.988.

${ }^{32}$ Mālik bin Ănas Al-Madanī, Muwatța’ al-Imām Mālik (Dār Ihyāa al-Turāth al-Arabī, n.d.)., 908.

${ }^{3}$ Aḥmad bin Ḥanbal Al-Shaibānī, Musnad Al-Imām Aḥmad Bin Ḥanbal (Mu'assasat alRisālah, 2001)., 424. 
Sijistānī menjelaskan bahwa yang dimaksud dengan 'ummāl (orang-orang yang diperkerjakan) adalah para pegawai yang bertanggung jawab atas hajat hidup orang banyak. Maka hadiah haram bagi mereka karena termasuk gulül. Mereka tidak boleh mengambilnya, dan orang lain tidak boleh memberikan kepada mereka. Larangan itu terjadi karena pemberian dapat berpengaruh terhadap mereka, misalnya orang yang diberi hadiah akan membantu orang yang memberinya, seperti memberinya sesuatu yang bukan haknya, memprioritaskannya dari yang lain, mengacuhkan hak yang tidak memberi dan menolong serta mendahulukan orang yang memberinya hadiah. ${ }^{34}$

Oleh sebab itu, Nabi saw. marah ketika ada pegawainya yang menerima gratifikasi pada saat melaksanakan tugas. Dikisahkan suatu waktu bahwa Rasulullah saw. mengutus salah seorang pegawainya bernama Ibn al-Lutbiyah ke suatu daerah untuk mengumpulkan zakat. Setelah selesai dari pekerjaannya, pegawai tersebut datang menghadap Nabi saw. dengan membawa 2 tas. 1 tas ia serahkan kepada Nabi saw. sebagai harta zakat yang berhasil ia kumpulkan, sedangkan 1 tas lainnya berisi hadiah yang ia dapatkan selama melaksanakan tugas dan tidak diserahkan kepada Nabi saw. dan diklaim sebagai "hadiah" untuknya. Nabi saw. kemudian dengan agak marah berkata kepada pegawainya itu: "mengapa kamu tidak duduk saja di rumah orang-tua kamu lalu lihat apakah ada orang yang datang membawa hadiah atau tidak". Oleh karena geramnya Nabi saw. atas perilaku pegawainya itu, setelah melaksanakan salat ia berdiri di hadapan orang banyak dan kembali bersabda:

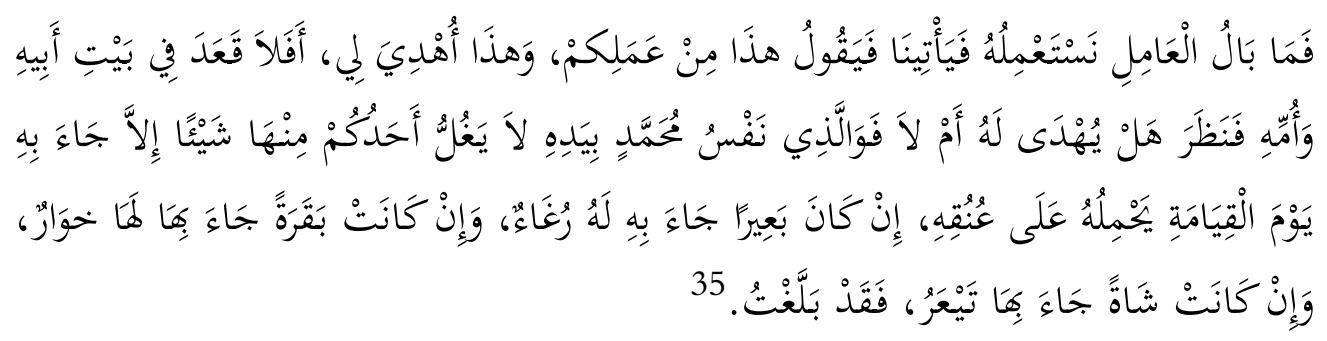

"Bagaimana mungkin ada pegawai yang kita beri suatu tugas, lalu ia kembali dan mengatakan, ini adalah hasil pekerjaan yang ditugaskan kepadanya, dan ini adalah hadiah untuk.ku. Mengapa ia tidak duduk-duduk saja di rumah orang-tuanya, lalu ia lihat, apakah ada orang yang datang memberinya hadiah atau tidake ada. Demi Allah yang jiwnaku berada dalam genggaman-Nya, tidaklah seseorang melakukan gulül terhadap sesuatu dari pekerjaannya, kecuali ia di akbirat nanti datang dengan memikunny di atas pundaknya. Jika yang dipikul itu unta, maka ia datang sambil mendengus, atau jika sapi, ia datang dengan melenguh, atau jika kambing, datang mengembik. Saya sudah sampaikan. (HR. al-Bukhari)

\footnotetext{
${ }^{34}$ Abd al-Muḥsin Al-'Abbād, Syarḥ Sunan Abì Dāwūd, n.d., 115.

${ }^{35}$ Muḥammad bin Ismāōil Al-Bukhārī, Saḥịh Al-Bukhārì (Damaskus: Dār Tūq al-Najāḥ, 1422)., 2446
} 
Setidaknya ada 2 hal yang perlu diperhatikan dari hadis ini. Pertama, Nabi saw. tidak senang perilaku pegawainya yang mendapat pemberian berupa hadiah, karena bagi Nabi saw. hadiah itu diberikan pasti berkaitan dengan tugas yang diberikan kepadanya atau kedudukan pegawai tersebut sebagai pengumpul zakat. Karena itulah, Nabi saw. mengatakan kepada pegawainya itu, duduk-duduk sajalah di rumah kamu, lalu lihat apakah ada orang yang datang membawa hadiah atau tidak? Pertanyaan yang sesungguhnya menafikan pemberian hadiah itu tanpa terkait dengan tugas yang diberikan kepadanya. Kedua, Ibn al-Lutbiyah menggunakan dalih "hadiah" sebagai alasan untuk menerima pemberian itu. Ini adalah modus yang sampai kini masih banyak menjadikan aparatur negara menerima gratifikasi. Padahal, hal ini jelas-jelas dilarang oleh Nabi saw.

Muhammad bin Salih al-Uthaimin menjelaskan hal ini dalam fatwanya bahwa hadiah bagi pegawai adalah termasuk korupsi, yaitu jika seseorang sebagai pegawai pemerintahan, dia diberi hadiah oleh seseorang yang berkaitan dengan pekerjaannya, maka hadiah semacam ini termasuk gulül. Hadiah seperti ini tidak boleh diambil sedikit pun oleh pegawai tadi walaupun diberikan dengan perasaan senang. ${ }^{36}$

Dengan demikian, seperti halnya dalam undang-undang, dalam hadishadis Nabi saw. juga dibedakan antara gratifikasi dengan suap. Gratifikasi sifatnya netral, sedangkan suap dilarang dalam agama. Gratifikasi juga bisa berkembang menjadi suap jika berkaitan dengan kedudukan atau jabatan aparatur negara yang menerima gratifikasi. al-Uthaimin berkata: "Tidak boleh bagi seorang pegawai di wilayah pemerintahan menerima hadiah berkaitan dengan pekerjaannya. Seandainya kita membolehkan hal ini, maka akan terbukalah pintu rishwah (suap/sogok). Uang sogok amatlah berbahaya dan termasuk dosa besar. Oleh karena itu, wajib bagi setiap pegawai jika dia diberi hadiah yang berkaitan dengan pekerjaannya, maka hendaklah dia mengembalikan hadiah tersebut. Hadiah semacam ini tidak boleh diterima, baik yang namanya hadiah, sedekah, dan zakat, tetap tidak boleh diterima. Lebih-lebih lagi jika dia adalah orang yang mampu, zakat tidak boleh bagi dirinya". ${ }^{37}$

Suap adalah tindakan memberikan uang, barang atau bentuk lain sebagai balasan dari pemberi suap kepada penerima suap yang dilakukan untuk mengubah sikap penerima atas kepentingan/minat si pemberi, walaupun sikap tersebut berlawanan dengan penerima. ${ }^{38}$ Dalam kamus hukum Black's Law Dictionary,

${ }^{36}$ Muḥammad bin Ṣālih bin Muḥammad Al-Uthaimīn, Majmū' al-Fatāwā Wa Rasāil Ibni Uthaimin (Dār al-Waṭn, n.d.)., 232.

${ }^{37}$ Ibid.

${ }^{38}$ Clinten Trivo Laoh, "Penegakan Hukum Terhadap Pelaku Tindak Pidana White Collar Crime,” Lex Crimen VIII, no. 12 (2019): 82-89. 
sebagaimana dikutip dari Clinten Trivo Laoh, penyuapan diartikan sebagai tindakan menawarkan, memberikan, menerima, atau meminta nilai dari suatu barang untuk mempengaruhi tindakan pegawai lembaga atau sejenisnya yang bertanggung jawab atas kebijakan umum atau peraturan hukum. ${ }^{39}$ Sedangkan penyuapan dalam Undang-undang Nomor 11 Tahun 1980 didefinisikan sebagai tindakan "memberi atau menjanjikan sesuatu kepada seseorang dengan maksud untuk membujuk supaya orang itu berbuat sesuatu atau tidak berbuat sesuatu dalam tugasnya, yang berlawanan dengan kewenangan atau kewajibannya yang menyangkut kepentingan umum"; juga "menerima sesuatu atau janji, sedangkan ia mengetahui atau patut dapat menduga bahwa pemberian sesuatu atau janji itu dimaksudkan supaya ia berbuat sesuatu atau tidak berbuat sesuatu dalam tugasnya, yang berlawanan dengan kewenangan atau kewajibannya yang menyangkut kepentingan umum". ${ }^{40}$

Dalam bahasa Arab suap dikenal sebagai rashwah atau rishwah. Rishwah adalah pemberian dari seseorang dengan maksud agar ia dimenangkan secara batil, atau agar ia diberi jabatan, atau agar digunakan untuk melakukan tindakan aniaya kepada orang lain. ${ }^{41}$ Abd al-Muhsin al-Abbad mendefinisikan rishwah sebagai sesuatu yang diberikan kepada pegawai negara atau kepada hakim atau kepada siapapun yang dikehendaki untuk sampai pada tujuan tertentu, baik tujuan itu benar maupun tidak. ${ }^{42}$ Sementara al-Qardawi mengatakan rishwab adalah suatu yang diberikan kepada seseorang yang memiliki kekuasaan atau jabatan tertentu untuk memenangkan perkaranya dengan mengalahkan lawannya sesuai dengan apa yang diinginkannya, atau untuk memberikan peluang kepadanya (misalnya seperti lelang/tender) atau untuk menyingkirkan lawan-lawannya. ${ }^{43}$

Nabi saw. melarang terjadinya rishwah dengan melaknat para pihak yang terlibat, baik pemberi, maupun penerima risywah. Al-Tirmizi meriwayatkan:

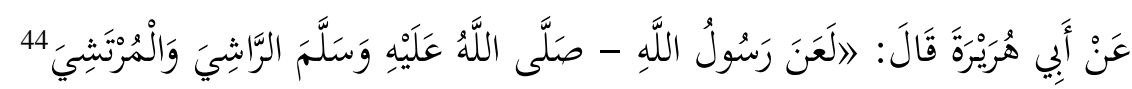

Dari Abu Hurairah ra. Rasulullah saw. melaknat orang yang menyogok dan orang yang disogok. (HR. al-Tirmiri).

Di hadis lain, al-Hakim meriwayatkan:

${ }^{39}$ Ibid.

40Undang-Undang No. 11 Tahun 1980 tentang Tindak Pidana Suap, Pasal 2.

${ }^{41}$ Ibn Hazm Al-Andalūsī, Al-Muhallā Bi al-Asar (Bairut: Dār al-Fikr, n.d.)., 157

${ }^{42}$ Al-'Abbād, Syarh Sunan Abì Däwūd., 113.

${ }^{43}$ Yūsuf al-Qarḍ̄āīi, Al-Halāl Wa al-Harām Fì al-Islām (Beirut: al-Maktabat al-'Ilmiyyah, 1980)., 320

${ }^{44}$ Muḥammad bin Isā Abū Isā Al-Tirmidhī, Sunan Al-Tirmidhì (Beirut: Dār Iḥyā al-Turāè al-Arabī, n.d.)., 623. 


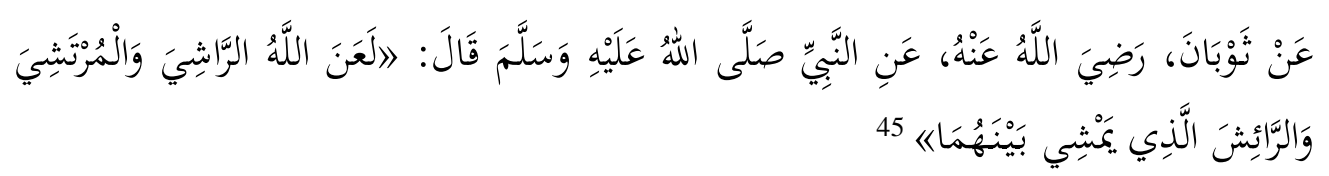

Dari Sauban ra. Nabi saw. telah bersabda: Allab melaknat orang yang menyogok, orang yang disogok dan orang yang menjadi perantara di antara keduanya. (HR. al-Hakim)

Demikian beberapa modus korupsi yang dapat ditemukan dalam teks-teks hadis Nabi saw. yang bersesuaian dengan ketentuan-ketentuan dalam perundangundangan yang berlaku di Indonesia. Seiring perkembangan zaman, modusmodus korupsi juga mengalami perkembangan dari waktu-ke waktu. Sebagian ada yang dapat dihubungkan dengan modus-modus yang telah ada, sebagian lainnya tidak. Juga ada modus yang sesungguhnya merupakan pelanggaran hukum tersendiri di luar korupsi, tetapi kemudian karena satu dan lain hal dimasukkan sebagai modus korupsi.

Dalam penelitian Indonesian Corruption Watch (ICW), modus suap merupakan modus operandi tertinggi yang dilakukan oleh para koruptor di Indonesia, dari 12 modus tindak pidana korupsi sepanjang tahun 2019. Total modus suap sebanyak 51 tindak pidana dengan nilai Rp169,5 miliar. ${ }^{46}$ Selain suap, modus korupsi lainnya adalah mark up, penyalahgunaan anggaran, penggelapan, penyalahgunaan wewenang, proyek fiktif, laporan fiktif, pungutan liar, gratifikasi, pemerasan, pemotongan, dan mark down. Sebagian dari modus ini sama atau dapat dianalogikan dengan modus korupsi dalam hadis-hadis Nabi saw. dan sebagian lainnya adalah modus baru yang tidak dibicarakan dalam hadis-hadis yang telah disebutkan. Modus korupsi akan terus bertambah dan berkembang seiring perkembangan zaman, dan bisa jadi akan semakin canggih. Sebagian dari modus itu mungkin saja adalah kejahatan tersendiri, tetapi kemudian dianggap sebagai kasus korupsi karena pelakunya adalah aparatur negara dan melibatkan keuangan negara.

\section{Kesimpulan}

Dari uraian yang telah dikemukakan dapat disimpulkan bahwa terdapat kesamaan antara hadis-hadis Nabi saw. dengan perundang-undangan yang berlaku sekarang tentang kaitan antara perilaku korupsi dengan aparatur negara. Dalam perundang-undangan dijelaskan bahwa subjek korupsi adalah mereka yang

${ }^{45}$ Abū Abdillāh al-Hākim Al-Naisabūrī, Al-Mustadrak Alā al-Ṣahịhain (Beirut: Dār alKutub al-Ilmiyyah, 1990)., 115.

${ }^{46} \mathrm{Ahmad}$ Al-Fiqri, “ICW Ungkap Modus Favorit Koruptor Curi Uang Rakyat,” Alinea.Id, 2020, https://www.alinea.id/nasional/icw-ungkap-modus-favorit-koruptor-curi-uang-rakyatb1ZIh9rCI. 
termasuk aparatur negara, yaitu pegawai negeri dan penyelenggara negara lainnya. Hal yang sama ditemukan dalam hadis-hadis Nabi yang selalu mengaitkan al-gubül sebagai padanan kata dari korupsi dengan 'ämil, yaitu orang yang diserahi tugas untuk mengurusi segala macam urusan umat. Jika al-gulül adalah padanan kata korupsi, maka 'ämil adalah padanan kata dari aparatur negara.

Kesamaan juga ditemukan pada pembahasan modus-modus korupsi. Modus seperti penyelewengan anggaran, penyalahgunaan kewenangan, penggelapan, serta gratifikasi dan suap, telah menjadi modus operandi dalam kejahatan korupsi sebagaimana ditemukan dalam hadis-hadis Nabi saw. dan sampai kini masih tetap menjadi modus utama korupsi dalam peraturan peundang-undangan. Modus korupsi ini kemudian bertambah dan berkembang seiring kemajuan zaman, sebagian masih dapat dianalogikan dengan modusmodus korupsi yang sudah ada, sebagian lainnya adalah modus baru yang tidak pernah disebutkan dalam hadis-hadis Nabi saw.

Atas dasar kesimpulan ini, maka diharapkan kepada para aparatur negara, pegawai negeri dan penyelenggara negara lainnya memiliki kesadaran dalam dirinya, bahwa keterlibatan dalam perbuatan korupsi tidak hanya bertentangan dengan aturan perundang-undangan yang berlaku, tetapi juga melanggar ajaran agama terutama hadis-hadis Nabi saw. dan bahwa keterlibatan dalam korupsi itu tidak hanya berakibat hukuman di dunia saja tetapi juga hukuman dan siksaan di akhirat kelak.

\section{Bibliografi}

Al-'Abbād, Abd al-Muḥsin. Syarh Sunan Abì Dāwūd, n.d.

Al-Andalūsī, Ibn Hazm. Al-Muhallā Bi al-Asar. Bairut: Dār al-Fikr, n.d.

Al-Athīr, Majduddīn ibn. Al-Nibāyat Fì Garīb al-Hadìth. XIII. Beirut: al-Maktabat al-'Ilmiyyah, 1978.

Al-Bukhārī, Muḥammad bin Ismāôìl. Șaḥịh Al-Bukhārì. Damaskus: Dār Tūq alNajāh, 1422.

Al-Fiqri, Ahmad. "ICW Ungkap Modus Favorit Koruptor Curi Uang Rakyat." Alinea.Id, 2020. https://www.alinea.id/nasional/icw-ungkap-modusfavorit-koruptor-curi-uang-rakyat-b1ZIh9rCI.

Al-Madan̄ī, Mālik bin Ănas. Muwațța' al-Imām Mälik. Dār Ihyā al-Turāth al-Arabī, n.d.

Al-Naisabūrī, Abū Abdillāh al-Hākim. Al-Mustadrak, Alā al-Ṣaḥhhain. Beirut: Dār al-Kutub al-Ilmiyyah, 1990.

al-Nawawī, Abū Zakariyā. Al-Minhäj Sharḥ Șaḥịh Muslim Bin al-Hajjäj. II. Bairut: Dār Iḥyā al-Turāth al-Arabī, n.d. 
al-Qarḍ̄̄wī, Yūsuf. Al-Halāl Wa al-Haràm Fì al-Islām. Beirut: al-Maktabat al'Ilmiyyah, 1980.

Al-Shaibānī, Aḥmad bin Ḥanbal. Musnad Al-Imām Aḥmad Bin Ḥanbal. Mu'assasat al-Risālah, 2001.

Al-Sijistānī, Abū Dāwūd. Sunan Abì Dāwūid. Bairut: al-Maktabat al-Așriyyah, n.d.

Al-Tirmidhī, Muḥammad bin Isā Abū Isā. Sunan Al-Tirmidhì. Beirut: Dār Iḥyā alTurāí al-Arabī, n.d.

Al-Uthaimīn, Muḥammad bin Șālih bin Muḥammad. Majmǜ al-Fatāwā Wa Rasäil Ibni Uthaiminn. Dār al-Wațn, n.d.

Departemen Pendidikan Nasional. Kamus Besar Bahasa Indonesia. Jakarta: PT. Gramedia Pustaka Utama, 2008.

Ḥamīd, Șālih bin Abdillāh bin. Nadrat Al-Naìm Fi Akblāq al-Rasūl al-Karim. XI. Jeddah: Dār al-Wasīlah, n.d.

Kadir, Yusrianto, and Roy Marthen Moonti. "Pencengahan Korupsi Dalam Pengelolaan Dana Desa." Jurnal IUS (Kajian Hukum Dan Keadilan) 6, no. 3 (2018): 431-42. doi:http://dx.doi.org/10.29303/ius.v6i3.583.

Kurniawan, Muhammad Rezza, and Pujiyono Pujiyono. "Modus Operandi Korupsi Pengadaan Barang Dan Jasa Pemerintah Oleh Pns." Law Reform 14, no. 1 (2018): 115. doi:10.14710/lr.v14i1.20241.

Laoh, Clinten Trivo. "Penegakan Hukum Terhadap Pelaku Tindak Pidana White Collar Crime.” Lex Crimen VIII, no. 12 (2019): 82-89.

Mamalu, Jastianra. "Penggelapan Barang Sitaan Narkotika Dalam Perkara Tindak Pidana." Lex et Societatis II, no. 2 (2014): 15-22.

Manzur, Jamāluddīn Muḥammad bin Mukarram al-Ifrīqī al-Misrī Ibnu. Lisān AlArab. XI. Beirut: Dār al-Sādir, 1994.

Mardiana Arsjad. "Gratifikasi Pelayanan Seksual Sebagai Tindak Pidana Korupsi." Jurnal Akta Yudisia 3, no. 1 (2018). doi:10.35334/ay.v3i1.988.

Nasution, Rasina Padeni. "Proyek Fiktif Sebagai Modus Korupsi Di Indonesia." TAQNIN: Jurnal Syariah Dan Hukum 2, no. 02 (2020): 53-65. doi:10.30821/taqnin.v2i02.8438.

Republik Indonesia. "Undang-Undang Republik Indonesia Nomor 31 Tahun 1999 Tentang Pemberantasan Tindak Pidana Korupsi," 1999, 1-30.

Santoso, Topo. "Menguak Relevansi Ketentuan Gratifikasi Di Indonesia." Jumal Dinamika Hukum 13, no. 3 (2013): 402-14. 
Sasongko, Agus. "Menjadi Amil, Apa Syaratnya?" Republika.Co.Id, 2019. https://republika.co.id/berita/dunia-islam/wakaf/pnxs74313/menjadiamil-apa-syaratnya.

Suhartono, Arif. "Subyek Hukum Tindak Pidana Korupsi," 2012. http://jpuarifsuhartono.blogspot.com/2012/06/subyek-hukum-tindakpidana-korupsi.html\#: :text=Subyek hukum adalah orang yang,adalah orang perseorangan termasuk korporasi.

Sumarwoto. "Status Hukum Bagi Koruptor Menurut Hukum Islam.” In Seminar Korupsi. Surakarta: Universitas Surakarta, 2014.

Syaifulloh, Abvianto. "Peran Kejaksaan Dalam Pengembalian Kerugian Keuangan Negara Pada Perkara Tindak Pidana Korupsi." Indonesian Journal of Criminal Law 1, no. 1 (2019): 47-64. doi:10.31960/ijocl.v1i1.147.

Syarif, Zainuddin. "Upaya Islam Dalam Membendung Budaya Korupsi." KARSA: Journal of Social and Islamic Culture 17, no. 1 (2010): 51-58. doi:https://doi.org/10.19105/karsa.v17i1.95.

Tambayong, Theresia C. "Profesionalisme Birokrasi Aparat Pemerintah Dalam Pelaksanaan Pelayanan Publik Di Kecamatan Tomohon Selatan Kota Tomohon." Politico V, no. 1 (2016).

Triyanto, Gatot. "Ratio Legis Perbedaan Rumusan Delik Pasal 2 Dan Pasal 3 Undang-Undang Nomor 31 Tahun 1999 Jo. Undang-Undang No. 20 Tahun 2001 Tentang Pemberantasan Tindak Pidana Korupsi." RECHTENS Volume VI (2017): 46-65.

Wibowo, Ari. "Penentuan Kriteria Unsur Penyalahgunaan Wewenang Dalam Perkara Tindak Pidana Korupsi (Studi Putusan Pengadilan)." Jurnal Y uridis 7, no. 1 (2020): 120-48. doi:http://dx.doi.org/10.35586/jyur.v7i1. 